\title{
Implementasi Cloud Storage Menggunakan OwnCloud yang High-Availability
}

\author{
Ikhwan Ar-Razy ${ }^{1)}$, Rinta Kridalukmana ${ }^{2)}$, Eko Didik Widianto ${ }^{2)}$
}

Program Studi Sistem Komputer Fakultas Teknik Universitas Diponegoro

Jalan Prof. Sudharto, Tembalang, Semarang, Indonesia

\begin{abstract}
Implementation of practicum courses in Department of Computer Engineering Diponegoro University has some drawbacks, one of them is a lot of lab assistant and the practitioner experiencing difficulties in terms of archiving. One solution to solve the problem is implementing a shared file storage system that is easy and can be accessed by both practitioners or lab assistants.

The purpose of this research is to build a cloud-based storage systems that are reliable to preventing crash damage hardware and high availability. The purpose of this research is achieved by designing the appropriate methodology.

The result of this research is a storage system that is on the server side by using virtualization and data replication (DRBD) as a storage method. The system is composed of two physical servers and one virtual server. Physical servers are using Proxmox VE as operating system and virtual server is using Ubuntu Server as operating system. OwnCloud applications and files are stored in the virtual server. File storage system has several major functions, which are: upload, download, user management, remove, and restore. The functions are executed through web pages, desktop application and Android application.
\end{abstract}

Keywords: Cloud-base storage, high availability, Proxmox VE, OwnCloud, file storage

\section{PENDAHULUAN}

Kegiatan praktikum pada program studi Sistem Komputer Universitas Diponegoro merupakan sebuah kegiatan perkuliahan yang bertujuan meningkatkan keahlian mahasiswa agar lebih menguasai ilmu perkuliahan. Namun, pelaksanaan praktikum di program studi Sistem Komputer Universitas Diponegoro memiliki beberapa kekurangan, salah satunya yaitu para asisten praktikum dan praktikan kesulitan dalam hal pengarsipan. Banyak laporan-laporan praktikum yang kurang tertata keberadaannya sehingga banyak para praktikan kesulitan saat membuat laporan praktikum.

Solusi yang ditawarkan untuk mengatasi masalah tersebut yaitu dengan membuat sebuah sistem penyimpanan bersama yang mudah dan bisa diakses oleh praktikan maupun asisten praktikum. Sistem penyimpanan bersama yang akan dibangun merupakan sebuah sistem penyimpanan yang berada pada sisi server. Penyimpanan pada sisi server atau pada saat ini lebih dikenal sebagai cloud computing merupakan teknologi dimana para pemilik data melakukan penyimpanan data di server storage dan dengan adanya hal itu tentu saja akan memudahkan penggunanya saat mengakses data dan tanpa harus menghabiskan memori penyimpanan pribadi.

Menurut C. Hewitt dalam sebuah jurnal : Cloud computing adalah suatu paradigma di mana informasi secara permanen tersimpan di server dan tersimpan secara sementara di komputer pengguna (client) termasuk di dalamnya adalah desktop, komputer tablet, notebook, komputer tembok, handheld, sensor-sensor, monitor dan lain-lain[1]. Cara kerja cloud computing adalah pengguna dapat mengakses berkas, data, program dan layanan pada web browser melalui internet yang disediakan oleh ISP. Pengguna hanya membayar untuk sumber daya komputasi dan jasa yang digunakan.

Beberapa penelitian dan penerapan cloud computing sebagai solusi penyimpanan data sudah banyak dilakukan dan diterapkan. Salah satu penelitian tersebut yaitu penelitian yang dilakukan oleh Onno W. Purbo mengenai pembuatan cloud computing dengan menggunakan infrastruktur open source [2]. Penggunaan open source bisa menekan biaya produksi dan bisa memanfaatkan kelebihan dari komunitas yang dimiliki open source. Penelitian yang sudah ada diharapkan bisa membantu saat pengembangan sistem penyimpanan ini.

\section{METODOLOGI PENELITIAN}

Metode penelitian yang digunakan adalah Network Development Life Cycle (NDLC), karena hasil penelitian berupa desain (perancangan) yang membutuhkan planning (perencanaan) yang melibatkan analisa kebutuhan perangkat keras dan perangkat lunak, analisa kebutuhan pengguna serta analisa topologi jaringan tempat penelitian [3]. Tahapantahapan penelitian NDLC terdiri dari 6 tahapan, yaitu analisa, desain, simulasi, implementasi, monitoring dan manajemen.

Tahap analisa adalah tahapan mengenai analisa kebutuhan perangkat, analisa permasalahan yang muncul, dan analisa topologi atau jaringan yang akan dibangun. Kebutuhan sistem yang perlu dibangun adalah Data Center dan Online Storage. Data Center digunakan untuk keperluan pendistribusian data yang dinamis berupa penyimpanan data dan pengolahan data. Online Storage digunakan sebagai adalah media penyimpanan data online dengan teknologi Cloud Computing yaitu layanan Cloud Storage yang dilengkapi sistem Management User dan Management Files [4].

Tahap desain adalah pembuatan gambar desain topologi jaringan dan arsitektur sistem yang akan dibangun. Topologi dan arsitektur sistem yang dirancang mengacu pada hasil dari data-data yang didapat pada tahap analisa.

Tahap simulasi yang dilakukan adalah penggunaan alat bantu sebuah PC Virtual untuk mencegah kesalahankesalahan yang mungkin terjadi. Tahap sismulasi dilakukan dengan menggunakan aplikasi Oracle Virtual Box versi Windows. Tahap simulasi bisa dilakukan bersamaan dengan tahap implementasi.

Tahap implementasi adalah tahapan penerapan semua yang telah direncanakan dan didesain sebelumnya. Penerapan yang dilakukan yaitu pemasangan dan konfigurasi server fisik, konfigurasi server virtual, serta 
pemasangan perangkat sesuai dengan desain jaringan yang telah dilakukan.

Tahap monitoring adalah tahapan evaluasi dan pengawasan terhadap sistem yang telah dibuat. Evaluasi yang dilakukan adalah pengujian terhadap sistem yang telah diimplementasikan. Pengujian terhadap sistem terbagi menjadi beberapa pengujian, yaitu pengujian terhadap replikasi data DRBD, pengujian kemampuan HA, dan pengujian fungsi-fungsi OwnCloud menggunakan web browser, aplikasi desktop dan perangkat android.

Tahap manajemen mengatur mengenai pengaturan pengguna yang bisa mengakses server fisik dan server virtual. Pembatasan hak akses bertujuan agar sistem yang telah dibuat bisa dikelola dengan baik dan tertata.

\section{PERANCANGAN DAN IMPLEMENTASI SISTEM}

\section{A. Topologi Jaringan dan Arsitektur Sistem}

Topologi jaringan menjelaskan mengenai bentuk fisik dari jaringan dan arsitektur sistem akan membahas mengenai cara kerja sistem dan perilaku sistem. Gambar 1 memperlihatkan perangkat-perangkat yang terdapat pada jaringan tersebut adalah Server 1, Server 2, Router, Switch, dan Perangkat Client. Pada sisi server adalah Server 1, Server 2, Router dan Switch, sedangkan pada sisi Client adalah perangkat bergerak seperti laptop dan smartphone. Media penyimpanan pada sisi server menggunakan replikasi data dengan menggunakan DRBD.

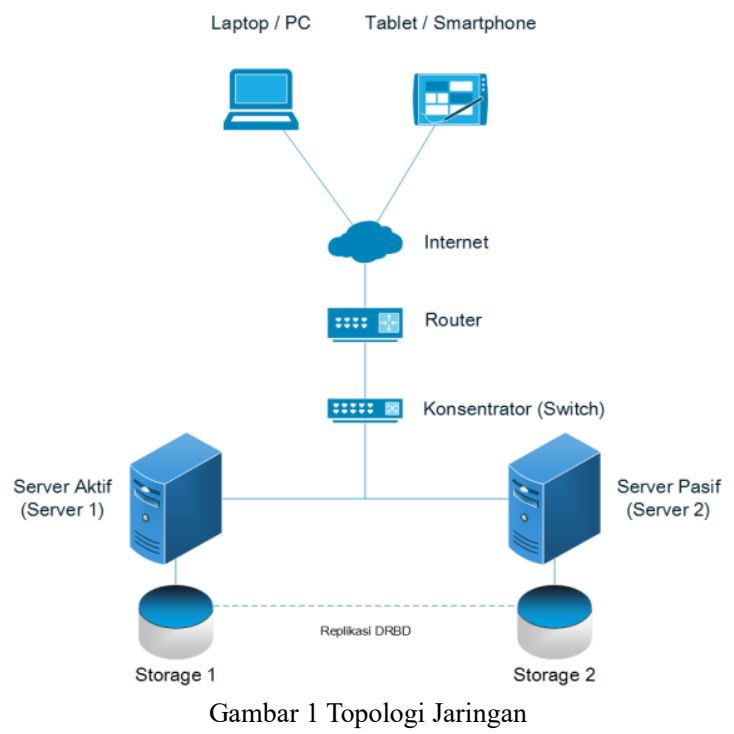

Media penyimpanan terdapat pada kedua Server 1 dan Server 2 dengan kapasitas penyimpanan yang sama yaitu 80 GB pada masing-masing server Replikasi data berjalan dengan menggunakan aplikasi DRBD yang merupakan aplikasi untuk membantu dalam pengembangan dan manajemen media penyimpanan. Data dari VM disimpan pada sebuah penyimpanan bersama sehingga VM tersebut bisa diakses oleh kedua server. VM yang juga bertindak sebagai server berjalan dengan Sistem Operasi Ubuntu Server 14.04. OwnCloud 8.0 dipasang di VM dan berjalan dengan layanan dari Ubuntu Server 14.04.

Gambar 2 menunjukkan bahwa sistem dibangun dan dijalankan pada 2 server yang pada masing-masing server dijalankan dengan sistem operasi. Server 1 merupakan sebuah server virtualisasi yang menjadi perangkat utama yang akan menjalankan tugas sebagai penyedia layanan cloud. Server 1 berjalan dengan Sistem Operasi Proxmox VE 3.3 dan di dalamnya terdapat VM yang menggunakan sistem operasi Ubuntu Server. Server 2 adalah server yang tetap stand by dan akan menjalankan layanannya jika Server 1 mati maka Server 2 akan menjalankan layanannya sama seperti yang dilakukan oleh Server 1. Server 2 berjalan dengan Sistem Operasi Proxmox VE 3.3.

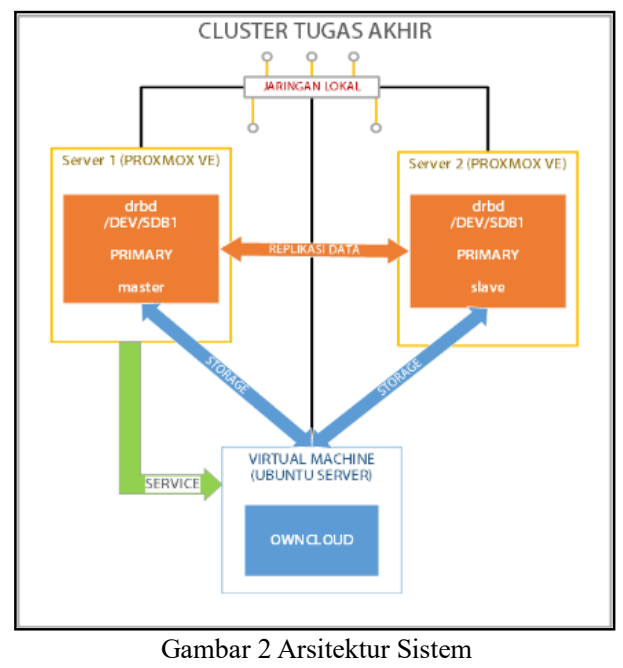

\section{B. Cara Kerja Sistem}

Cara kerja sistem Cloud Storage terbagi menjadi dua, yaitu cara kerja sistem Cloud Storage dan sistem HighAvailability. Cloud Storage bekerja dan berjalan pada sistem bermula dari client yang mengakses OwnCloud dengan menggunakan web browser maupun menggunakan aplikasi native yang disediakan oleh OwnCloud dan bisa diunduh oleh client di website resmi OwnCloud.

Salah satu metode yang bisa digunakan yaitu dengan menggunakan cluster HA dengan menggunakan 2 server yang menjalankan sistem operasi Proxmox VE pada kedua server [5]. Gambar 3 menunjukkan client mengakses cloud storage melalui web browser. Client menulis alamat web atau ip server secara dengan menggunakan web browser dan client akan berhadapan dengan sebuah form login. Jika client berhasil login maka sistem akan mengarahkan ke halaman tampilan Home Owncloud. Namun, jika client gagal login maka akan kembali lagi ke halaman form login sampai client berhasil login.

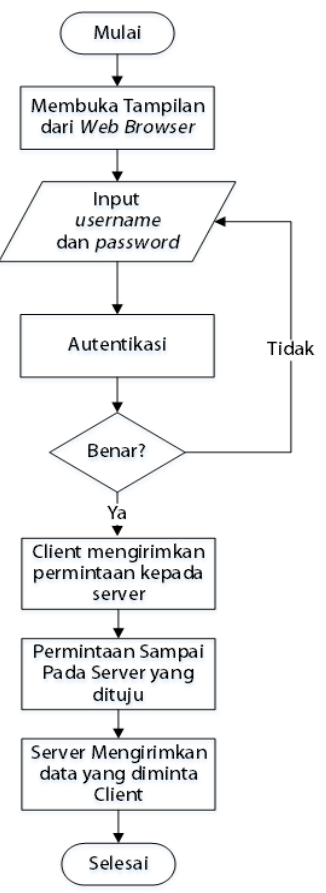

Gambar 3 Flowchart cara kerja sistem cloud storage 
Flowchart pada Gambar 4 menjelaskan bahwa sistem di awali dengan menjalankan kedua server, yaitu Server 1 dan Server 2. Saat kedua server sudah up dan sudah berjalan, maka Server 1 akan menjadi server yang menjalankan servis untuk VM dan Server 2 akan stand by menunggu Server 1 mati.

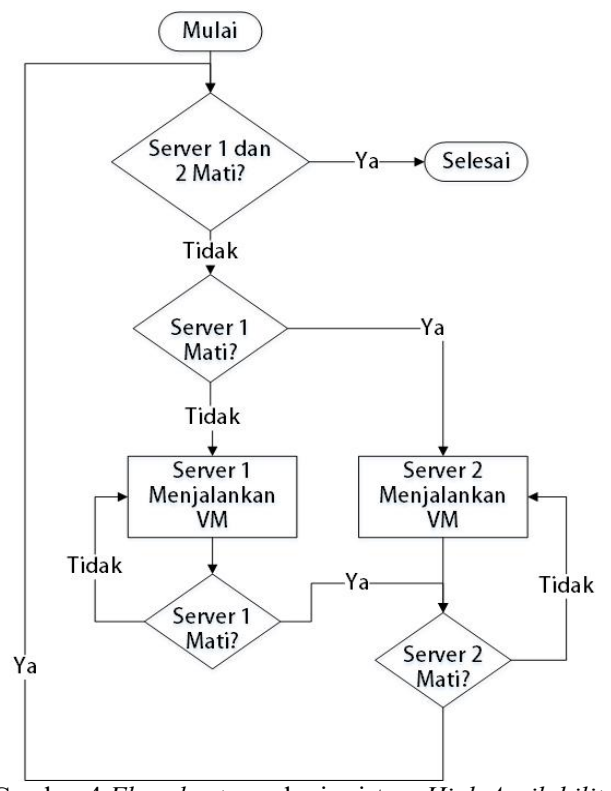

Gambar 4 Flowchart cara kerja sistem High Availability

VM dijalankan oleh Server 1 dan apabila Server 1 mati maka Server 2 akan menjalankan servis dan VM akan dijalankan di Server 2. Kemudian servis akan dijalankan kembali oleh Server 1 jika sudah menyala.

\section{Implementasi}

Implementasi sistem yang dilakukan berdasarkan topologi jaringan serta arsitektur sistem yang telah dirancang pada tahap desain. Gambar 5 memperlihatkan penerapan dari topologi jaringan yang telah dirancang. Komputer yang digunakan sebagai Server 1 memiliki spesifikasi perangkat keras berupa prosesor AMD Athlon II 245 2,9 GHz yang memiliki fitur AMD-V, memori sebesar 4048 MB DDR3, penyimpanan SATA Hard Disk sebanyak 2 buah yang masing-masing berukuran $80 \mathrm{~GB}$. Komputer yang digunakan sebagai Server 1 memiliki spesifikasi perangkat keras berupa prosesor Intel Core 2 Duo E6750 2,1 GHz yang memiliki fitur Intel-VT, memori sebesar 3036 MB DDR3, penyimpanan SATA Hard Disk sebanyak 2 buah yang berukuran $80 \mathrm{~GB}$.

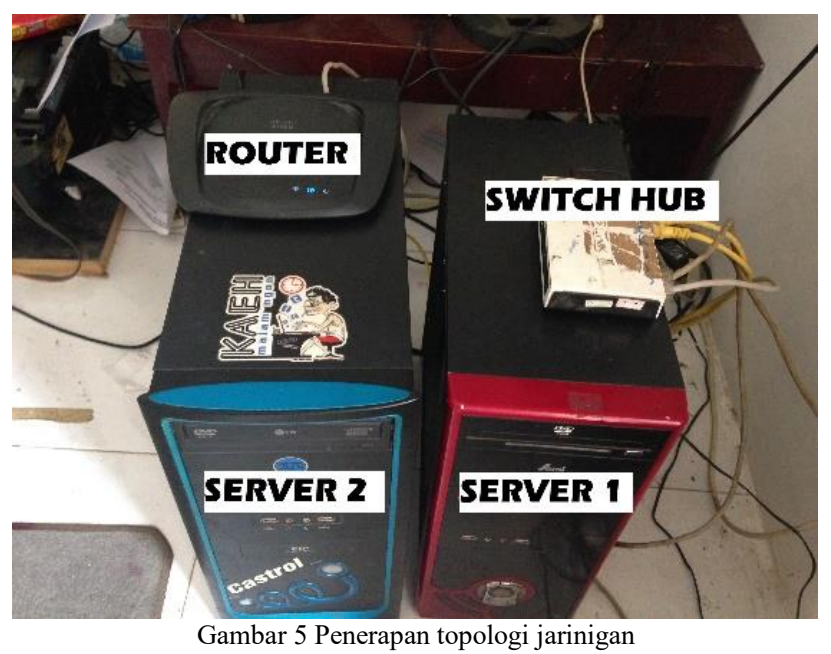

Beberapa perangkat dan komponen teknologi jaringan yang digunakan untuk penelitian ini adalah kabel LAN UTP, konektor RJ-45 bertipe straight sebagai media transmisinya, Switch Hub TPLink, Router Linksys X2000, Network Card yang digunakan berasal dari Mainboard Server.

Perangkat lunak yang digunakan untuk mengembangkan sistem Cloud Storage terdiri dari Sistem Operasi dan aplikasi khusus, yaitu Proxmox VE 3.3, Ubuntu Server 14.04, Web Browser dengan Java Support. Proxmox VE Merupakan sistem operasi yang digunakan pada Server 1 dan Server 2. Proxmox VE adalah distro khusus yang didedikasikan secara khusus sebagai mesin host virtualisasi sistem dan memuat 2 teknologi virtualisasi, yaitu KVM dan OpenVZ. Ada beberapa aplikasi yang digunakan pada Proxmox VE untuk pengembangan penelitian ini, yaitu pvecm sebagai pengatur cluster dan DRBD untuk mengatur shared storage dan membuat volume group sehingga media penyimpanan dari Server 1 dan Server 2 bisa tersinkron. DRBD merupakan sebuah aplikasi sebagai solusi untuk replikasi penyimpanan (hard disk, partisi, logical volumes, dan lain-lain) antar dua server pada Linux.

Virtual Machine (VM) yang berjalan pada Proxmox VE menggunakan sistem operasi Ubuntu Server 14.04[6]. Ubuntu Server merupakan sebuah Sistem Operasi berbasis Linux yang dikembangkan oleh Chanonical[7]. Terdapat beberapa aplikasi yang akan digunakan pada sistem operasi ini, yaitu LAMP sebagai web-server dan pengatur database di dalamnya sudah termasuk MySQL dan PhpMyAdmin, dan OwnCloud 8.0. MySQL merupakan sebuah aplikasi untuk mengatur berkas dan menjalankan berkas tersebut secara online melalui web browser[8]. OwnCloud merupakan sebuah perangkat lunak pada sisi server untuk melayani manajemen berkas dan pengguna berbasis cloud computing.

\section{IV.PENGUJIAN SISTEM}

Pengujian yang dilakukan terhadap sistem terdiri dari empat pengujian, yaitu pengujian kehandalan server, pengujian replikasi DRBD, pengujian HA dari Server 1 dan Server 2 dalam mengatur VM, pengujian fungsi-fungsi yang ada di OwnCloud.

\section{A. Pengujian Kehandalan Server}

Pengujian yang dilakukan terhadap perangkat keras dan perangkat lunak dari Server1, Server 2 dan VM. Pengujian kehandalan perangkat keras berupa pengujian kehandalan CPU dan I/O. Sedangkan pengujian kehandalan perangkat lunak berupa pengujian kehandalan MySQL.

\section{Kehandalan CPU}

Uji kehandalan CPU dilakukan dengan menggunakan aplikasi sysbench yang dipasang pada Server 1, Server 2 dan VM100. Metode yang dilakukan yaitu dengan melihat waktu yang dibutuhkan CPU untuk memproses bilangan prima dengan batas 20000 dengan menggunakan 1 thread.

Hasil dari pengujian kehandalan yang dilakukan oleh Server 1 dan Server 2 ditunjukkan pada Tabel 1. Waktu ratarata dari Server 1 saat menjalankan VM adalah 31,7598 dan saat tanpa VM adalah 31,7065 detik. Waktu rata-rata dari Server 2 saat menjalankan VM adalah 59,3780 dan saat tanpa VM adalah 59,3780 detik. Hal tersebut memperlihatkan bahwa Server 1 dan Server 2 memiliki beban tambahan saat menjalankan VM. Perbedaan waktu pemrosesan antara Server 1 dan Server 2 dalam mengolah data dikarenakan kecepatan prosesor pada masing-masing server berbeda. Server 1 yang memiliki kecepatan prosesor 
yang lebih tinggi dibanding Server 1 mempengaruhi hasil pengujian kehandalan CPU.

Tabel 1 Kehandalan CPU Server 1 dan Server 2

\begin{tabular}{|c|c|c|c|}
\hline \multirow{2}{*}{$\begin{array}{c}\text { Lokasi } \\
\text { VM100 }\end{array}$} & \multicolumn{2}{|c|}{ Waktu rata-rata (detik) } & \multirow{2}{*}{ Perbedaan } \\
\cline { 2 - 3 } & $\begin{array}{c}\text { Server 1 } \\
(@ \mathbf{2 , 9 0} \text { Ghz })\end{array}$ & $\begin{array}{c}\text { Server 2 } \\
(@ \mathbf{2 , 6 6} \text { GHz })\end{array}$ & \\
\hline Server 1 & 31,7598 & 59,2071 & 27,4473 \\
\hline Server 2 & 31,7065 & 59,3780 & 27,6715 \\
\hline
\end{tabular}

Kehandalan CPU pada VM100 ditunjukkan pada Tabel

2. Tabel 2 menunjukkan bahwa kecepatan VM100 saat berjalan pada Server 1 adalah 31,8676 dan pada saat berada pada Server 2 adalah 59,5465. Hasil yang tunjukkan memperlihatkan bahwa kecepatan CPU dari VM100 dipengaruhi oleh CPU dari server fisik yang menjalankan VM tersebut.

Tabel 2 Kehandalan CPU VM100 (UbuntuServer)

\begin{tabular}{|c|c|}
\hline Lokasi VM100 & Waktu rata-rata (detik) \\
\hline Server 1 & 31,8676 \\
\hline Server 2 & 59,5465 \\
\hline
\end{tabular}

\section{Kehandalan I/O}

Pengujian kehandalan I/O dilakukan pada Server 1 dan Server dengan menggunakan aplikasi sysbench menggunakan perintah fileio. Metode yang dilakukan oleh sysbench yaitu dengan melakukan operasi baca, tulis, dan lainnya yang dilakukan selama 100 detik terhadap I/O dari Server 1 dan Server 2.

Hasil yang didapatkan berupa kecepatan rata-rata server dalam membaca dan menulis melalui I/O. Tabel 3 menunjukkan hasil uji kehandalan I/O server. Hasil yang didapatkan yaitu Server 1 membaca dengan kecepatan ratarata $1,0441 \mathrm{Mb}$ /detik dan kecepatan rata-rata dalam menulis sebesar 0,6959 Mb/detik. Sedangkan Server 2 dapat membaca dengan kecepatan rata-rata 1,1062 Mb/detik dan menulis dengan kecepatan rata-rata $0,7375 \mathrm{Mb} /$ detik.

Tabel 3 Kehandalan Baca dan Tulis pada Server 1 dan Server 2

\begin{tabular}{|c|c|c|c|c|c|c|c|c|}
\hline \multirow{2}{*}{$\begin{array}{c}\text { Perang- } \\
\text { kat }\end{array}$} & $\begin{array}{c}\text { Wa } \\
\text { ktu } \\
\text { (Detik) }\end{array}$ & Baca & Tulis & Lainnya & Jumlah & $\begin{array}{c}\text { Ukuran } \\
\text { Berkas } \\
(\mathbf{M b})\end{array}$ & \multicolumn{2}{|c|}{$\begin{array}{c}\text { Kecepatatan rata-rata } \\
\text { (Mb/detik) }\end{array}$} \\
\cline { 5 - 9 } & & & & & & Baca & Tulis \\
\hline Server 1 & \multirow{2}{*}{100} & 6682 & 4454 & 14028 & 25344 & 174 & 1,0441 & 0,6959 \\
\cline { 3 - 8 } & 7080 & 4720 & 14978 & 26778 & 184,38 & 1,1062 & 0,7375 \\
\hline
\end{tabular}

Hasil yang didapatkan menunjukkan bahwa Server 2 lebih handal dibanding Server 1 dalam pengujian kehandalan I/O. Hal tersebut dikarenakan adanya perbedaan spesifikasi memori, motherboard, harddisk dan prosesor.

\section{Kehandalan MySQL}

Pengujian MySQL dilakukan dengan menggunakan aplikasi sysbench yang dipasang pada VM100 (UbuntuServer). Metode yang digunakan yaitu menghitung kecepatan rata-rata VM100 (UbuntuServer) dalam memproses transaksi tiap detiknya. Transaksi yang dilakukan adalah sebanyak 50000 baris perintah. Operasi yang dilakukan yaitu dengan membaca barisan perintah tersebut.

Tabel 4 memperlihatkan hasil kecepatan rata-rata dari pengujian MySQL. Pada saat VM100 berjalan di Server 1 MySQ1 memproses 817,99 transaksi/detik, sedangkan saat berjalan di Server 2 MySQL memproses 565,61 transaksi/detik.

Tabel 4 Kehandalan MySQL pada VM100 (UbuntuServer)

\begin{tabular}{|c|c|}
\hline Lokasi VM100 & Kecepatan rata-rata (transaksi/detik) \\
\hline Server 1 (@2,90 GHz) & 817,99 \\
\hline Server 2(@2,66 GHz) & 565,61 \\
\hline
\end{tabular}

Perbedaan hasil yang didapatkan pada saat VM100 berjalan di Server 1 dan Server 2 disebabkan karena spesifikasi komputer Server 1 dan Server 2 yang berbeda.
Spesifikasi server fisik yang menjalankan VM sangat mempengaruhi kinerja server VM.

\section{B. Pengujian DRBD}

Pengujian DRBD dilakukan untuk membuktikan bahwa replikasi yang dilakukan pada Server 1 dan Server 2 berjalan dengan benar. Replikasi dilakukan dengan membuat sebuah berkas pada Server 1 yang nantinya bisa diakses pada Server 2.

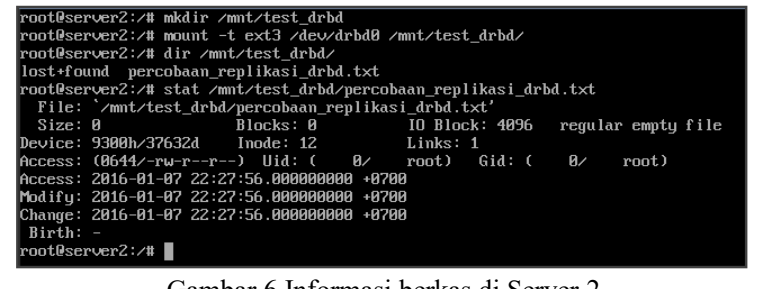

Gambar 6 Informasi berkas di Server 2

Gambar 6 menunjukkan informasi dari file yang sama dengan yang terlihat pada Server 1. Hal ini membuktikan bahwa konfigurasi dan pengujian terhadap replikasi data pada DRBD telah berhasil dan sesuai dengan hasil yang diinginkan, yaitu berkas yang dibuat pada Server 1 pada Drbd0 telah berhasil dimuat pada Server 2.

\section{Pengujian $H A$}

Pengujian HA merupakan pengujian terhadap kemampuan Server 1 dan Server 2 dalam menjalankan failover VM yang sedang berjalan. Metode yang digunakan adalah dengan melakukan PING terhadap VM 100 yang memiliki IP Address 192.168.1.101. Ping dilakukan dengan menggunakan interval waktu yaitu 0.1 detik. Waktu down VM 100 dicari dengan melihat icmp_seq yang hilang dari barisan ping.

Tabel 5 Percobaan waktu Failover dan Migrasi

\begin{tabular}{|c|c|c|c|c|}
\hline \multirow{2}{*}{ Percobaan } & \multicolumn{2}{|c|}{$\begin{array}{c}\text { Dari Server 1 ke } \\
\text { Server 2 }\end{array}$} & \multicolumn{2}{c|}{$\begin{array}{c}\text { Dari Server 2 ke } \\
\text { Server 1 }\end{array}$} \\
\cline { 2 - 5 } & Failover & Migrasi & Failover & Migrasi \\
\hline 1 & 38,1 & 0,5 & 32,1 & 0,4 \\
\hline 2 & 32,8 & 0,4 & 33,4 & 0,5 \\
\hline 3 & 32,2 & 0,4 & 32,7 & 0,5 \\
\hline 4 & 32,4 & 0,4 & 33,2 & 0,4 \\
\hline $\begin{array}{c}\text { Waktu rata- } \\
\text { rata }\end{array}$ & 33,88 & 0,43 & 32,80 & 0,45 \\
\hline
\end{tabular}

Pengujian yang dilakukan dengan menggukan metode ping menghasilkan sebuah waktu rata-rata down dari VM 100 yang didapatkan pada saat terjadi failover, yaitu 33,88 detik dan 32,80 detik. Hal ini membuktikan bahwa failover VM sukses dilakukan dengan waktu down yang sangat kecil. Migrasi yang dilakukan menghasilkan sebuah waktu ratarata down dari VM 100 selama 0,43 detik dari Server 1 ke Server 2 dan selama 0,45 detik dari Server 2 ke Server 1.

\section{Pengujian OwnCloud} Manajemen Pengguna

Pengujian manajemen pengguna merupakan pengujian terhadap fungsi-fungsi yang ada pada OwnCloud dalam menggatur pengguna. Pengujian manajemen pengguna dilakukan dengan login sebagai AdminOwnCloud. Pengujian manajemen pengguna yang dilakukan adalah membuat pengguna, memperbarui pengguna, menghapus pengguna, membuat grup, dan menghapus grup. Tabel 6 menunjukkan hasil dari pengujian terhadap fungsi-fungsi manajemen pengguna. Semua pengujain yang dilakukan, yaitu membuat pengguna, memperbarui pengguna, menghapus pengguna, membuat grup, dan menghapus grup telah mendapatkan hasil seperti yang diharapakan. 
Tabel 6 Pengujian manajemen pengguna

\begin{tabular}{|c|c|c|c|}
\hline $\begin{array}{c}\text { Nama } \\
\text { Pengujian }\end{array}$ & $\begin{array}{c}\text { Bentuk } \\
\text { Pengujian }\end{array}$ & $\begin{array}{c}\text { Hasil yang } \\
\text { diharapkan }\end{array}$ & $\begin{array}{c}\text { Hasil } \\
\text { Pengujian }\end{array}$ \\
\hline $\begin{array}{l}\text { Pengujian } \\
\text { Membuat } \\
\text { pengguna }\end{array}$ & $\begin{array}{c}\text { Admin membuat } \\
\text { pengguna dengan } \\
\text { memasukkan } \\
\text { username dan } \\
\text { password pada } \\
\text { halaman Users }\end{array}$ & $\begin{array}{l}\text { Muncul sebuah } \\
\text { pengguna baru } \\
\text { pada halaman } \\
\text { Users yang } \\
\text { berupa username } \\
\text { dan nama } \\
\text { lengkap }\end{array}$ & Berhasil \\
\hline $\begin{array}{l}\text { Pengujian } \\
\text { Menghapus } \\
\text { pengguna }\end{array}$ & $\begin{array}{c}\text { Admin } \\
\text { menghapus salah } \\
\text { satu pengguna } \\
\text { yang ada halaman } \\
\text { Users }\end{array}$ & $\begin{array}{c}\text { Pengguna akan } \\
\text { dihapus dari } \\
\text { sistem OwnCloud } \\
\text { dan tidak bisa } \\
\text { login } \\
\end{array}$ & Berhasil \\
\hline $\begin{array}{l}\text { Pengujian } \\
\text { Membuat } \\
\text { grup }\end{array}$ & $\begin{array}{l}\text { Admin membuat } \\
\text { grup dengan } \\
\text { memasukkan } \\
\text { nama grup }\end{array}$ & $\begin{array}{l}\text { Tercipta sebuah } \\
\text { grup untuk } \\
\text { pengguna }\end{array}$ & Berhasil \\
\hline $\begin{array}{c}\text { Pengujian } \\
\text { Menghapus } \\
\text { grup }\end{array}$ & $\begin{array}{c}\text { Admin } \\
\text { menghapus grup }\end{array}$ & $\begin{array}{c}\text { Grup yang ada } \\
\text { akan terhapus } \\
\text { secara permanen }\end{array}$ & Berhasil \\
\hline
\end{tabular}

Gambar 7 menampilkan halaman pengguna. Pengguna yang sudah didaftarkan ke dalam sistem penyimpanan sudah bisa login ke dalam sistem penyimpanan tersebut. Penggunaan grup dimaksudkan untuk memudahkan dalam pengelompokan pengguna.

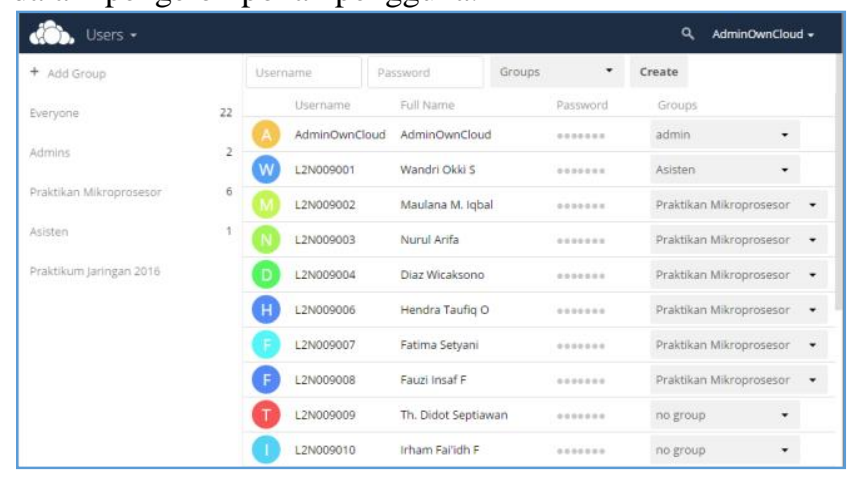

Gambar 7 Tampilan Halaman Users

\section{Manajemen Berkas}

Pengujian manajemen berkas merupakan pengujian terhadap fungsi-fungsi OwnCloud dalam mengatur berkas. Pengujian manajemen berkas adalah unggah, unduh, hapus, dan restore berkas. Sistem berhasil dalam menguji fungsi unggah, unduh, hapus, dan restore. Hasil dari pengujian terhadap manajemen berkas ditunjukkan pada Tabel 7. Tabel 7 Pengujian manajemen berkas

\begin{tabular}{|c|c|c|c|}
\hline $\begin{array}{c}\text { Nama } \\
\text { Pengujian }\end{array}$ & Bentuk Pengujian & $\begin{array}{c}\text { Hasil yang } \\
\text { diharapkan }\end{array}$ & $\begin{array}{c}\text { Hasil } \\
\text { Pengujian }\end{array}$ \\
\hline $\begin{array}{c}\text { Pengujian } \\
\text { unggah }\end{array}$ & $\begin{array}{c}\text { Mengunggah } \\
\text { berkas dari } \\
\text { perangkat } \\
\text { pengguna ke } \\
\text { OwnCloud }\end{array}$ & $\begin{array}{c}\text { Berkas berhasil } \\
\text { diunggah dan } \\
\text { bisa diakses dari } \\
\text { halaman web }\end{array}$ & Berhasil \\
$\begin{array}{c}\text { Pengujian } \\
\text { unduh }\end{array}$ & $\begin{array}{c}\text { Mengunduh berkas } \\
\text { dari OwnCloud ke } \\
\text { perangkat } \\
\text { pengguna }\end{array}$ & $\begin{array}{c}\text { Berkas berhasil } \\
\text { diunduh dan } \\
\text { disimpan di } \\
\text { perangkat milik } \\
\text { pengguna }\end{array}$ & Berhasil \\
Pengujian & $\begin{array}{c}\text { Menghapus berkas } \\
\text { yang ada di } \\
\text { OwnCloud }\end{array}$ & $\begin{array}{c}\text { Berkas } \\
\text { berpindah ke } \\
\text { folder Deleted } \\
\text { files }\end{array}$ & Berhasil \\
\hline $\begin{array}{c}\text { Pengujian } \\
\text { restore }\end{array}$ & $\begin{array}{c}\text { Mengembalikan } \\
\text { berkas yang ada di } \\
\text { Deleted Files }\end{array}$ & $\begin{array}{c}\text { Berkas berhasil } \\
\text { dikembalikan ke } \\
\text { lokasi sebelum } \\
\text { berkas dihapus } \\
\text { ke Deleted Files }\end{array}$ & Berhasil \\
\hline
\end{tabular}

Gambar 8 menunjukkan halaman Files yang diakses oleh pengguna. Pengguna bisa mengkses berkas yang diunggah dan bisa mengunduh berkas yang ada pada halaman berkas tersebut. Fungsi hapus bertujuan untuk menghapus berkas yang sekiranya tidak dibutuhkan lagi.

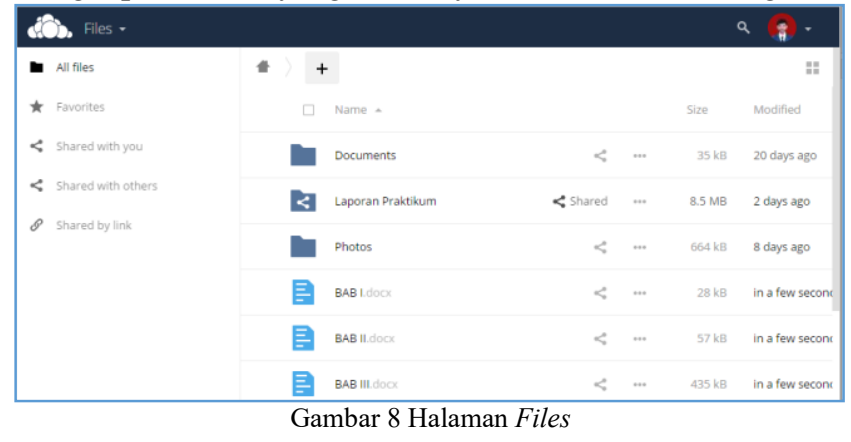

Gambar 9 menampilkan jendela Deleted Files yang ada pada OwnCloud. Fungsi restore bertujuan untuk mengembalikan berkas yang sudah terhapus. Penghapusan berkas masih bisa dilihat di dalam folder Deleted Files yang kemudian bisa dikembalikan ke lokasi awal ataupun dihapus secara permanen.

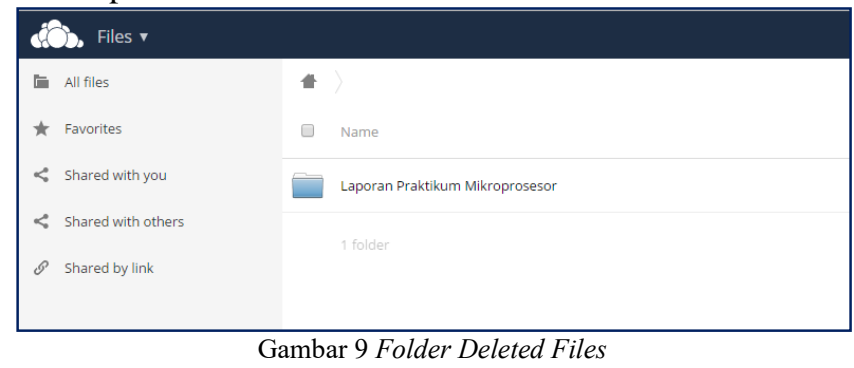

\section{Aplikasi Client OwnCloud Desktop}

OwnCloud memiliki aplikasi client OwnCloud Desktop untuk sistem operasi Windows. Gambar 10 menampilkan tampilan folder OwnCloud yang ada pada komputer client dan OwnCloud akan melakukan sinkronisasi dengan server. Direktori tersebut akan selalu tersinkronisasi dengan folder-folder dan berkas-berkas yang ada pada server. Dan server juga akan selalu tersinkronisasi dengan direktori tersebut.

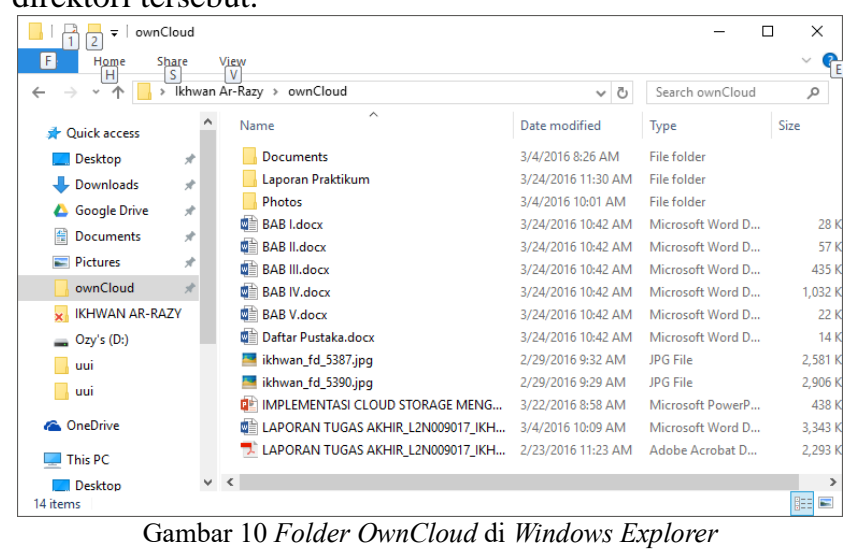

\section{Aplikasi Client OwnCloud Android}

Gambar 11 memperlihatkan tampilan pada aplikasi OwnCloud berisi folder-folder dan berkas-berkas yang sudah tersinkronisasi dengan server dan aplikasi desktop. Aplikasi OwnCloud Android hanya memiliki fungsi manajemen berkas dan tidak memiliki fungsi manajemen pengguna. 


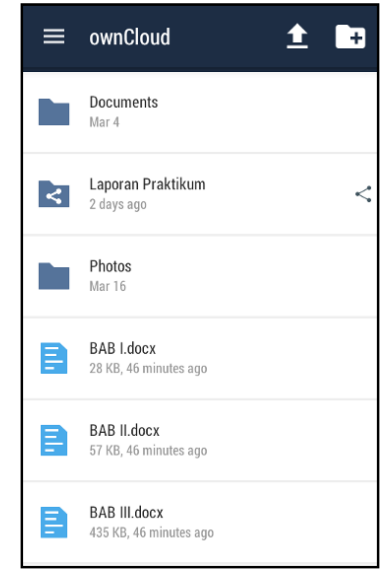

Gambar 11 Tampilan antar muka OwnCloud Android

\section{PENUTUP}

\section{A. Kesimpulan}

Dari hasil perancangan, implementasi, pengujian dan analisa yang telah dilakukan terhadap sistem HA dan aplikasi OwnCloud, dapat disimpulkan bahwa: (1) Pengujian kehandalan CPU berhasil dilakukan pada Server 1, Server 2, dan VM100. Server 1 mendapatkan nilai lebih tinggi dibanding Server 2 hal tersebut dikarenakan kecepatan komputasi dan pemrosesan dari masing-masing server berbeda. (2) Pengujian kehandalan I/O berhasil dilakukan pada Server 1 dan Server 2. Server 2 mendapatkan nilai lebih tinggi dibanding Server 1. Hal tersebut dikarenakan spesifikasi dari kedua server yang berbeda. (3) Kecepatan komputasi VM100 bergantung dengan kecepatan komputer Server dimana VM itu berjalan. Jika VM100 berjalan pada Server 1 maka kecepatan komputasinya akan menyesuaikan dengan komputasi Server 1 dan jika VM100 berjalan pada Server 2 maka kecepatan komputasinya akan menyesuaikan dengan komputasi Server 2. (4) Replikasi data yang dilakukan DRBD berhasil dilakukan dengan melakukan mounting disk Drbd0 pada Server 1 dan Server 2 dengan ukuran disk Drbd0 sebesar 80 GB. (5) Metode pemindahan VM 100 dari Server 1 ke Server 2 berhasil menjalankan VM 100 dengan metode failover HA dan migrasi. (6) Pengujian yang dilakukan dengan menggukan metode ping menghasilkan sebuah waktu rata-rata down dari VM 100 yang didapatkan pada saat terjadi failover, yaitu 33,88 detik dan 32,80 detik. Migrasi yang dilakukan menghasilkan sebuah waktu rata-rata down dari VM 100 selama 0,43 detik dari Server 1 ke Server 2 dan selama 0,45 detik dari Server 2 ke Server 1. (7) Sistem penyimpanan berkas memiliki beberapa fungsi utama, diantaranya adalah: unggah, unduh, manajemen pengguna, hapus, dan restore. Fungsi-fungsi tersebut telah berhasil berjalan melalui halaman web, aplikasi desktop dan aplikasi berbasis Android.

\section{B. Saran}

Dari hasil perancangan, implementasi, pengujian dan analisa yang telah dilakukan terhadap sistem Cloud Storage dapat disarankan bahwa: (1) Diperlukan penelitian lanjutan mengenai analisa penyimpanan bersama dalam suatu jaringan sebagai metode penyimpanan sistem. Penyimpanan bisa dengan menggunakan Network Attached Storage (iSCSI atau NFS). (2) Penelitian lanjutan untuk membandingkan kecepatan media penyimpanan VM dengan jenis file system yang berbeda. (3) Penelitian lanjutan mengenai penggunaan autentikasi dengan LDAP pada sistem penyimpanan OwnCloud.

\section{DAFTAR PUSTAKA}

[1] C. Hewitt, "ORGs for Scalable, Robust, PrivacyFriendly Client Cloud Computing," IEEE Internet Comput., vol. 12, no. 5, pp. 96-99, Sep. 2008.

[2] O. W. Purbo, Membuat Sendiri Cloud Computing Server Menggunakan Open Source. Yogyakarta: Penerbit Andi, 2012.

[3] J. E. Goldman and P. T. Rawless, "Chapter 10: The Network Development Life Cycle," in Applied Data Communications: A Business-Oriented Approach, Wiley, 2004.

[4] J. E. Smith and R. Nair, Virtual Machines: Versatile platforms for sistems and processes. USA: Morgan Kaufmann Publishers, 2005.

[5] S. van Vugt, Pro Linux High Availability Clustering. New York: Apress, 2014.

[6] I. Sofana, Teori \& Praktik Cloud Computing (Opennebula, Vmware \& Amazon Aws). Bandung: Penerbit Informatika, 2013.

[7] A. Askari, Debian GNU / Linux, 2nd ed. Bandung: Penerbit Informatika, 2011.

[8] B. Raharjo, Modul Pemrograman Web (HTML; PHP; MySql) Revisi Kedua. Bandung: Penerbit Informatika, 2014. 